IZA DP No. 8701

Fixed Exchange-Rate Policy and Real Wage Growth: Quasi-Experimental Evidence

Corrado Andini

December 2014 


\title{
Fixed Exchange-Rate Policy and Real Wage Growth: Quasi-Experimental Evidence
}

\author{
Corrado Andini \\ Universidade da Madeira, \\ CEEApIA and IZA
}

\section{Discussion Paper No. 8701 December 2014}

IZA

P.O. Box 7240

53072 Bonn

Germany

Phone: +49-228-3894-0

Fax: +49-228-3894-180

E-mail: iza@iza.org

Any opinions expressed here are those of the author(s) and not those of IZA. Research published in this series may include views on policy, but the institute itself takes no institutional policy positions. The IZA research network is committed to the IZA Guiding Principles of Research Integrity.

The Institute for the Study of Labor (IZA) in Bonn is a local and virtual international research center and a place of communication between science, politics and business. IZA is an independent nonprofit organization supported by Deutsche Post Foundation. The center is associated with the University of Bonn and offers a stimulating research environment through its international network, workshops and conferences, data service, project support, research visits and doctoral program. IZA engages in (i) original and internationally competitive research in all fields of labor economics, (ii) development of policy concepts, and (iii) dissemination of research results and concepts to the interested public.

IZA Discussion Papers often represent preliminary work and are circulated to encourage discussion. Citation of such a paper should account for its provisional character. A revised version may be available directly from the author. 
IZA Discussion Paper No. 8701

December 2014

\section{ABSTRACT \\ Fixed Exchange-Rate Policy and Real Wage Growth: Quasi-Experimental Evidence}

Using Difference-in-Differences estimation and data from the European Community Household Panel, this paper suggests that the fixed exchange-rate policy adopted by Italy in the 1997-2000 period has reduced the real hourly wage growth of Italian full-time workers with permanent contracts, on average, by $3 \%$. Yet, the cost of the policy has been ultimately paid by the private sector where real wage growth has decreased by $5.4 \%$.

JEL Classification: J31, C23

Keywords: wages, productivity, difference-in-differences

Corresponding author:

Corrado Andini

Universidade da Madeira

Campus da Penteada

9000-390 Funchal

Portugal

E-mail: andini@uma.pt

* The views expressed in this paper are those of the author and do not necessarily reflect those of the institutions he is affiliated with. 


\section{Introduction}

Figure 1 depicts the evolution of real GDP per hour worked in Italy from 1970 to 2013. Many have noted that labour productivity kept growing slower since around 1996. This observation has inspired an intensive search for explanations (Daveri and Jona-Lasinio, 2005; Daveri and Parisi, 2010; Hassan and Ottaviano, 2013; Manasse, 2013; Nannicini, 2013a; Nannicini, 2013b; Lippi and Schivardi, 2014; Pellegrino and Zingales, 2014; to cite a few). Among these, one that has attracted the attention of media and the public is the possible association between this productivity slowdown and the exchange-rate policy adopted by Italy after 1996 (Bagnai, 2013) ${ }^{1}$.

In November 1996, Italy adopted a fixed exchange-rate policy. It was not the first time the country adopted such policy, but it was the first time this policy was adopted in an environment characterized by free capital mobility, central bank independence, and a new system of industrial relations (the so-called protocollo d'intesa of July 1993).

Of course, it is difficult to say something about causality. Has the fixed exchange-rate policy caused - or partly caused - the slowdown of the real hourly productivity growth? Such question can only be truly answered if a credible quasi-experimental study could be set up. The latter should be based on internationally comparable micro data on productivity and its determinants. Since we do not have access to this type of data, this paper tries to answer a related question, namely: Has the fixed exchange-rate policy adopted by Italy after 1996 caused a decline of the real hourly wage growth of Italian workers? By "Italian workers" we mean individuals working in Italy, not necessarily Italian citizens.

The question about wages is related to that about productivity because real hourly wage and real hourly productivity are widely seen by economists as strongly associated. In addition, the question is interesting and policy relevant by itself for its implications on income distribution, consumption and growth. Yet, in order to answer it, we need to set up a credible quasi-experimental exercise.

The difficulty in international macroeconomics is not only that one typically lacks the counterfactual - what would have happened if Italy had not adopted a fixed exchangerate policy - but also that a counterfactual can only be artificially built using data from at least one different country. While examples of quasi-experimental studies exploiting

\footnotetext{
${ }^{1}$ This book has already sold more than 20,000 copies.
} 
differences across states, regions, municipalities, firms and individuals of the same country are common, these approaches are not useful to evaluate the effects of an exchange-rate policy because all units of the same country are treated by the policy. To the best of our knowledge, this paper innovates by using individual-level data from a different country as counterfactual. Yet, this choice does not come at zero cost, as shall be discussed later. In particular, we use a Difference-in-Differences (DiD) approach, and data from the United Kingdom (UK) as counterfactual. The advantage of this approach is that we do not need the treated and the controls to be "equal at the baseline". We mainly need them to belong to "parallel worlds".

\section{Methodology and data}

The link between exchange rates and labour-market outcomes is a classical topic in international macroeconomics. The works authored by Goldstein (1974), Sachs (1980), Dornbusch (1987), Djajić (1988), Andersen and Sørensen (1988), Collins and Park (1989), Burgess and Knetter (1998), Lawler (2000), Goldberg and Tracy (2000, 2001), Campa and Goldberg (2001), Mishra and Spilimbergo (2011), Wright and Bastos (2012), Schmitt-Grohé and Uribe (2012, 2013), Galí and Monacelli (2013) are just few examples. However, we are not aware of any study investigating the impact of an exchange-rate policy choice on economic outcomes using a counterfactual approach, besides one recent contribution by Manasse et al. (2013).

The authors studied the effects of the euro on the Italian economy and came up with an original idea to create a reliable counterfactual. They used a "synthetic-control" approach and exploited the information from aggregate time-series data for each country in their sample. They considered that the treatment took place since January 1999 and analyzed what would have happened to the Italian economy, if the country had not joined the euro. The authors reported that most indicators of the Italian performance would not have changed, thus suggesting that the euro should not be seen as the cause of the Italian recent problems. However, they did find that the dynamics of real productivity has been negatively affected by the adoption of the euro.

As stressed before, this study by Manasse et al. (2013) is particularly relevant because, to the best of our knowledge, it is the first attempt to analyze the effects of an exchangerate policy choice, such as the adoption of the euro, in a quasi-experimental setting. 
However, a lot of heterogeneity is likely to be disguised by the use of aggregate timeseries data.

We depart from previous work along two directions. On the one hand, as stressed before, we try to do a step onwards with respect to Manasse et al. (2013) by using individual-level data. On the other hand, we do a step back by focusing on the years immediately prior to the birth of the euro. The latter choice is justified on the ground that, as already seen, the Italian productivity slowdown started before the birth of the euro. Most importantly, the structural change in the management of the nominal exchange rate in Italy happened in November 1996, not in January 1999.

The construction of a DiD exercise requires several steps. First, we must define the treatment variable, the treated group, the control group, the pre-treatment period and the treatment period. Then, one has to check whether the so-called "parallel trends assumption" is satisfied.

Let us start with the treatment variable and the treatment period. We use wage data from the European Community Household Panel (ECHP). This is a well known individuallevel longitudinal dataset which reports micro data for 15 countries. The waves go from 1994 to 2001. However, the data reported in the dataset in each wave sometimes refer to the previous year. This is the case with individual wages. For example, wage data reported in the 1994 wave refer to wages earned in 1993 and so on. This means that, in principle, we have access to actual data on individual wages from 1993 to 2000. Since the data are annual, our treatment variable will be defined annually.

Figure 2 shows that, at the peak, in April 1995, the exchange rate between the Italian lira and the ecu (European currency unit) was at the level of 2,296.16 liras per ecu. After a revaluation started in May 1995, which led to an exchange rate of 1,932.35 liras per ecu in November 1996, Italy re-joined the European Monetary System (EMS). Since then, the exchange rate history of the country has been simple. The rate was kept around the value of 1,936.27 liras per ecu, which will become the official rate of conversion when, in January 1999, the euro experience started. The euro entered in circulation in January 2002.

Since we use annual wage data from 1993 to 2000 in our DiD exercise, our treatment variable is the fixed exchange-rate policy adopted by Italy in the 1997-2000 period. Given that we have data only from 1993 onwards, the pre-treatment period will be from 
1993 to 1996 . Of course, the treated group is formed by individuals working in Italy during the 1997-2000 period.

As a control group, we use individuals working in the UK. This is for one basic reason. Among the ECHP countries, the only two that had a flexible exchange-rate policy in the pre-treatment period and did not abandon it in the treatment period were the UK and Sweden (Denmark did not join the euro but had a fixed exchange-rate policy similar to that of Italy after 1996). We could have chosen Sweden. However, for Sweden, the ECHP does not provide data for the whole pre-treatment period (the waves start in 1997, reporting wages from 1996 onwards). Thus, the only country that can actually be used as a control group is the UK. Interestingly, both Italy and the UK exited the EMS in September 1992.

In particular, the wage data for the UK in the ECHP dataset are of two types: those collected by the European Commission (Eurostat), which are only available for the waves from 1994 to 1996, and those borrowed from British Household Panel Survey (BHPS), which cover all relevant years. The BHPS data are adapted to the ECHP variables and thus perfectly comparable with the data for Italy, which are available for the entire period of interest.

It is worth noting that, in $\mathrm{DiD}$ exercises, we do not need to compare groups with similar characteristics. We need that the mean outcome variables in the two groups - the treated and the controls - are parallel in the pre-treatment period, conditional on the set of explanatory variables we control for. In this study, we do not just assume the latter, as sometimes done in $\mathrm{DiD}$ studies. We test for the parallel trends assumption by following the approach suggested by Centeno and Novo (2013). Provided that we actually have parallelism in the pre-treatment period, then a break of parallelism in the treatment period can be attributed to the treatment.

As a matter of curiosity, comparing the lines of real GDP per hour worked in Italy and the UK in Figure 3, we can see that they followed roughly parallel patterns until 1995 , with Italy being more productive. The relative decline of Italian productivity started since around 1996. From 1997 to 2000, the ratio of Italy to UK productivity declined from $104.5 \%$ to $99.5 \%$. The Italian real productivity declined $4.7 \%$ relative to the British. By 2000 the gap between the UK and Italy was closed. Since then, the British economy has been more productive than the Italian. Analogously, looking at Figure 4, we can see that the ratio of Italy to UK real hourly wage declined from $119.4 \%$ to 
$101.3 \%$ in the $1997-2000$ period. The Italian real hourly wage declined $15.1 \%$ relative to the British. Of course, we cannot draw any causal implication from these graphs because a lot of individual and firm heterogeneity is hidden behind aggregate data, and we do not. However, we can get an idea of the numbers in place.

In addition, Figure 3 provides new insights on the analysis of the causes of the Italian productivity slowdown. On the one hand, it is trendy to attribute all the recent problems of the Italian economy to rigidities in product, labour and credit markets, which do exist and cannot be disregarded. However, on the other hand, all these rigidities were already in place before Italy joined the EMS in November 1996 and, despite them, the Italian economy was not underperforming with respect to a much more flexible economy, such as the British (a similar argument applies to the inefficiencies in public administration, corruption, and so on). Joining the EMS implied an additional rigidity for Italy: that of the nominal exchange rate. Perhaps, further research is needed to uncover the causal effects of this additional rigidity on several outcomes. This paper makes a step in this direction. The next section focuses on wages as outcome.

\section{Empirical strategy}

We estimate the following DiD model:

$$
\ln w_{i t}=\psi_{1} \text { Treat }_{i t}+\psi_{2} \text { After }_{i t}+\psi_{3} \text { Treat }_{i t} \times \text { After }_{i t}+\psi_{4} \operatorname{lncpi}_{i t}+X_{i t} \beta+e_{i t}
$$

The variable $\ln w_{i t}$ is the logarithm of the nominal gross hourly wage. The matrix $X_{i t}$ is a set of individual characteristics including education levels (primary, secondary and tertiary), individual age, age squared, gender, job status (whether the individual is supervisor, intermediate, and lower-intermediate), marital status (whether the individual is married or not), health (presence of chronic health problems), sector of production (agriculture $^{2}$, industry ${ }^{3}$, and services ${ }^{4}$ ), migration status (whether the individual is an

\footnotetext{
${ }^{2}$ This category includes: 1) agriculture, hunting, and forestry; and 2) fishing.

3 This category includes: 1) manufacturing; 2) mining; 3) electricity, gas and water supply; and 4) construction.

${ }^{4}$ This category includes: 1) wholesale and retail commerce and repair activities; 2) hotels and restaurants; 3) transportation, storage and communication; 4) financial intermediation; 5) real estate, renting and business activities; 6) public administration, defense and compulsory social security; 7) education; 8) health and social work; 9) other services.
} 
immigrant or not), sector of activity (whether the individual works in the public sector or not), and finally information on occupations. ${ }^{5}$

The variable Treat $_{i t}$ is defined for each year $t$ and equals to one for the treated group individuals working in Italy - and zero for the control group - individuals working in the UK. The variable After it $_{\text {is }}$ defined for each individual $i$ and equals to one from 1997 onwards - when the fixed exchange-rate policy is officially in place in Italy. Thus, the coefficient of the interaction term Treat $_{i t} \times$ After $_{i t}$ identifies the impact of the policy change - the adoption of a fixed exchange-rate policy in Italy. In particular, if we consider just two periods - the pre-treatment period 1 and the treatment period 2 - then $\psi_{3}=\left(\ln w_{T 2}-\ln w_{T 1}\right)-\left(\ln w_{C 2}-\ln w_{C 1}\right)$ where $\ln w_{T 2}$ is the conditional average $\log$ wage for the treated in the treatment period, $\ln w_{T 1}$ is the same object in the pretreatment period, $\ln w_{C 2}$ is the conditional average log wage for the controls in the treatment period and $\ln w_{C l}$ is the same object in the pre-treatment period. The difference $\left(\ln w_{T 2}-\ln w_{T 1}\right)$ represents the average wage growth for the treated in presence of the policy. The difference $\left(\ln w_{C 2}-\ln w_{C 1}\right)$ represents the average wage growth for the treated in absence of the policy. Thus, $\psi_{3}$ provides the effect of the policy on the average wage growth for the treated.

Note that model (1) controls for the logarithm of the consumer price index, the variable $\operatorname{lncpi}_{i t}$, which varies over time and across individuals because those working in Italy face different prices than those working in the UK. This means that we can interpret the coefficient $\psi_{3}$ as the impact of the policy on the average real wage growth for the treated, ceteris paribus, i.e. keeping individual productivity characteristics constant $\left(X_{i t}\right)$. The standard approach would use $\ln w_{i t}-\ln c p i_{i t}$ as dependent variable. However, this approach would implicitly assume that the coefficient of $\ln c p i_{i t}$ is equal to 1 with certainty. Since there is no economic reason to assume that a $1 \%$ increase in prices implies a $1 \%$ increase in nominal wages both on average and in every sector or industry of the economy, we prefer to use the log of the price index as a covariate, and thus allow for flexibility in the estimation of $\psi_{4}$.

\footnotetext{
${ }^{5}$ The occupation categories are nine: 1) legislators, senior officials and managers; 2) professionals; 3) technicians and associate professionals; 4) clerks; 5) service workers and shop and market sales workers; 6) skilled agricultural and fishery workers; 7) craft and related trades workers; 8) plant and machine operators and assemblers; and 9) elementary occupations.
} 
Before estimating model (1), we need to check whether the parallel trends assumption holds. As stressed before, we follow Centeno and Novo (2013) who estimate a model of the following type in the pre-treatment period:

$$
\ln _{i t}=\lambda_{1} \text { Treat }_{i t}+\lambda_{2} \text { Time }_{t}+\lambda_{3} \text { Treat }_{i t} \times \text { Time }_{t}+\lambda_{4} \ln _{\text {cpi }} i_{i t}+X_{i t} \beta+e_{i t}
$$

where Time $_{t}$ is a linear trend between 1993 and 1996.

If the trends are parallel, then the coefficient $\lambda_{3}$ is not statistically different from zero. This means that there is not a specific time trend of wages in Italy, conditional on the model covariates. Note, further, that it is not important whether the level of the mean log wage is different in Italy and the UK, or whether the levels of the covariates (say education) are different. All we need is parallelism in the pre-treatment period, and a reasonable argument to impute any change in parallelism to a single treatment: Italy's decision to adopt a fixed exchange-rate policy in an unprecedented economic environment (see above).

\section{Tricky points}

DiD exercises can be criticized by arguing that the treatment may be multiple, i.e. there might be other things changing in Italy after 1996. This is a limitation of most DiD studies, particularly when the treatment period extends over several years. Our study is not exempted. Nevertheless, we try to address this issue by dealing with three potentially confounding factors: the Treu reform, competition from China, and the Information-Technology (IT) revolution.

To keep into account that an important labour-market reform (legge 24 giugno 1997, $n$. 196) occurred in Italy in June 1997 - the so called Treu reform - which changed the legislation on temporary job contracts increasing their use, we focus our analysis on full-time wage earners with permanent contracts (p.c.) since $1993^{6}$.

Specifically, we focus on individuals in paid employment with complete 8-year work histories and we exclude individuals working with an employer in paid apprenticeship or training, self-employed, and unpaid workers in family enterprises. In addition, we

\footnotetext{
${ }^{6}$ Individuals are interviewed for the first time in 1994. Thus, their responses may refer to their job contracts in 1994 rather than 1993.
} 
exclude all part-time jobs. Finally, we exclude individuals with fixed-term or short-term contracts, causal work with no contract, and some other working arrangements. Summary sample statistics for treated and controls are reported in Appendix (Table A1 and Table A2).

Arguably, the wages of the workers in the sample (both Italian and British) have not been affected by the Treu reform. This argument is also consistent with the fact that the Treu law explicitly prohibited to pay lower wages to workers on temporary contracts performing the same jobs as workers on permanent contracts.

One peculiar aspect of the Treu reform was that the sectors of agriculture and construction were excluded by the application of the law, unless an explicit agreement between unions and employer organizations was achieved at a later stage. Yet, to the best of our knowledge, the agreement was not reached. This fact probably induced the organizations of private employers to put pressure on the legislator with an eye at obtaining the abrogation of this norm - the conditional exclusion of agriculture and construction - which partially occurred only in December 1999 (legge 23 dicembre 1999, $n$. 488). The abrogation was partial because it only interested a specific category of workers in the two sectors, the clerks, meaning that all the other categories of workers were still excluded. Hence, the permanent workers in the sectors of agriculture and construction can be considered as not affected by the Treu reform during the 19971999 period and only marginally affected in 2000 (by the potential competition of parttime clerks), thus providing a cleaner quasi-experimental setup, useful to make a robustness check.

As an additional robustness check, we will also test whether our results are robust to the inclusion of temporary and part-time workers in the sample.

Regarding the other two confounding factors mentioned before, a recent study by Pellegrino and Zingales (2014) has stressed that - besides the euro - the Italian economy has been exposed to two additional important shocks in the last 25 years: one is competition from China and one is the IT revolution. In particular, the authors attribute the "Italian disease" to the fact that the country was not able to react to the challenge posed by the Chinese competition and to take full advantage of the IT revolution.

We believe that both the "China" and "IT" shocks do not seriously affect our estimate of the treatment effect for following two reasons. First, China only joined the World Trade 
Organization (WTO) in 2001. Hence, the Chinese competition may have reduced real wage growth in Italy most likely after our treatment period. Second, the IT revolution occurred in the 1990s. It affected both treated and controls, both in the pre-treatment period and in the treatment period, thus being implicitly accounted for in our estimation strategy.

As a matter of fact, trade barriers started to decrease well before China joined the WTO. Yet the liberalization process was limited to few specific industries. For instance, one important change, which affected the textile and clothing industries worldwide, was the progressive elimination of the quantitative restrictions to imports of textile and clothing products, enforced by the Agreement on Textiles and Clothing (ATC) of December 1993.

Before the ATC signature, the European Economic Community (EEC) market was protected by the import quotas imposed under the Multi Fibre Agreement (MFA) of December 1973. The ATC was inspired by a liberalization principle. It designed a transition period during which a progressive phase-out on quotas had to be implemented. Four key dates and shares were agreed (Spinanger, 1999): 16\% of 1990 imports had to be liberalized since January 1995, 17\% since January 1998, $18 \%$ since January 2002, and the remaining 49\% since January 2005.

The Italian textile and clothing industry may have been affected by this shock. However, the magnitude of the shock was very similar in the pre-treatment period $(16 \%)$ and during the treatment period (17\%), thus being unlikely to bias our estimate of the policy treatment. In addition, most of the liberalization happened after the treatment period. Finally, the shock was not specific to Italy and its amplitude was limited to one specific industry.

Nevertheless, to exploit all the available information in the data, we go one step further. If the combination of lower trade barriers and Chinese competition really reduced real wage growth in Italy during the treatment period and the policy did not, then their effects should be concentrated among good-producing industries. We will make a robustness check along these lines.

A similar argument can be used for the IT revolution. If the IT revolution really had an impact on real wage growth during the treatment period and the policy did not, then its effects should be concentrated among service-producing industries. Nevertheless, it is 
difficult to make a robustness check in this case because we do not have a prior on the potential effect of the IT revolution. On the one hand, it may have increased real wage growth by increasing real productivity growth. On the other hand, it may have decreased real wage growth by replacing workers with technology. In principle, the two effects may have even offset each other.

Another possible criticism to our DiD approach is that treated and controls live in two different countries. Thus, the control group may have deviated from trend after 1996 due to some specific shock occurred in the British economy. While we cannot exclude such event, two things are worth noting. First, as stressed before, Figure 3 suggests that the British productivity has been roughly parallel to the Italian productivity until 1995 (included). It was the Italian productivity which deviated from earlier trend since around 1996. Second, Figure 4 suggests that parallelism characterizes the evolution of real wages in Italy and the UK. The lines are roughly parallel in 1970-1976, 1979-1983, 1984-1991 and finally 1991-1996. After 1996, while the British real wage recovered the 1984-1991 trend, the Italian real wage did not.

A further criticism is that the exchange-rate policy adopted by Italy after November 1996 not only has treated the Italian workers but also the British ones, through bilateral trade and capital movements, or even migration. Of course, such externalities cannot be ignored. Nevertheless, they are present in most of the existing DiD studies. For instance, if a reform affects the workers of one sector, they can move to other sectors used as control group, thus corrupting the quasi-experimental setup. On this specific point, an argument supporting our analysis is that, as a matter of fact, the economic links between Italy and the UK are not as tight as those between Italy and Germany, or Italy and France. Thus, the assumption we make is not "heroic" when compared to similar assumptions usually made in DiD studies.

Finally, the identification of model (1) can be criticized because it requires that any influence of the treatment on the set of covariates, which includes the log price index, does not affect the potential outcomes (Lechner, 2008) and that the treated do not change their behaviour - affecting the pre-treatment outcome - in anticipation of future treatment. These assumptions - unlike the one on parallel trends - cannot be directly tested. However, Section 5 will show that our main results are robust to the use of $\ln w_{i t}-\ln c p i_{i t}$ as dependent variable. Section 6 will discuss why we believe that a significant effect of the treatment on the pre-treatment outcome is unlikely. 
All empirical studies have their limitations. This study is no exception. However, we try to do our best to provide reliable causal estimates.

\section{Results}

Models (1) and (2) are estimated by ordinary least squares. As recommended by Bertrand et al. (2004), to avoid inconsistent standard errors due to the persistence of hourly wages, we estimate model (1) as a two-period model (pre-treatment and treatment), i.e. we treat data from 1993 to 1996 as if they were referring to one single period, and data from 1997 to 2000 as if they were referring to another single period.

The main coefficient of interest, $\psi_{3}$, is equal to -0.0305 and statistically significant at $1 \%$ level (Table 1). This means that the policy of adopting a fixed exchange rate after 1996 caused a reduction of the real hourly wage growth of full-time permanent workers in Italy by $3 \%$ on average in the $1997-2000$ period.

The parallel trends assumption is not rejected (Table 2). The coefficient $\lambda_{3}$ is not statistically significant. In addition, its positivity means that a small difference in trends in the pre-treatment period, if any, was in favour of the treated group. The latter further supports the idea of a negative impact of the treatment on Italian wages as these turned out to grow slower in the treatment period.

Using the same empirical strategy, it is also interesting to investigate to what extent our result is driven by specific groups of the working population (Table 1). In particular, we find that private-sector workers have been actually hit by the policy since their real wages grew less $5.4 \%$, while the dynamics of real wages in the public sector have not been affected.

In addition, within the private sector, we do not find evidence of relevant heterogeneity between industry (good-producing sectors) and services. Yet, services workers look a bit more penalized, on average. This result is supporting our analysis against the argument of the "China" bias.

As expected, the coefficient of the log price index is not necessarily equal to 1 with certainty (see further below). However, there are cases where $\psi_{4}$ is very close to 1 (all sectors, private sector, and private industry). In general, we have a trade-off between the 
potential endogeneity bias due to the use of the log price index as covariate and the potential distortion created by assuming that $\psi_{4}$ is equal to 1 with certainty. We have chosen the first of the two options because the variability of the coefficient of the log price index is likely to increase as we move from aggregated to more disaggregated data (see further below).

The parallel trends assumption is satisfied in all cases (Table 2), though less clearly in the case of the public-sector regression (the null can be rejected at $10 \%$ level).

If we further investigate heterogeneity within the private sector, we find some evidence of differentiated responses across industries (Table 3, see also Table A3 in Appendix). Seven out of eleven industries have negative coefficients above the average for the private sector (-0.0546), but the four industries with coefficients below the average (manufacturing, mining and utilities, commerce, and transportation) account for $62 \%$ of the observations in the private sector.

For private manufacturing, the evidence is in line with that obtained for the whole goodproducing sector (private manufacturing accounts for 10993 observations out of 13644). The impact coefficient is equal to -0.0487 and significant at $1 \%$ level (Table 3 ).

An important finding supporting the idea that our results are not driven by the potentially confounding effect of the Treu reform is that the real wage growth in the construction industry strongly decreased (-12\%, see Table 3$)$. A similar result is found for the agricultural sector $(-17 \%)$, though we should look at it with caution because the number of observations is low.

The finding for the construction industry is particularly interesting for two reasons. First, it is more robust to criticisms because the quasi-experimental setting is more restricted, say "better controlled" to use a medical expression. Even the "China" and "IT" biases are less likely to apply to this industry. In addition, if we make treated and controls in the construction industry more similar at the baseline by using kernel matching and we estimate model (1) on the common support, the estimate of the impact of the policy is even bigger (-16\%). Second, the construction-industry finding suggests that our result for all sectors may be, if anything, underestimated. This reinforces our conclusion of a negative causal effect of the treatment.

As expected, we find a lot of variability in the coefficient of the log price index across industries (Table 3), supporting our specification of the DiD model. 
Again, pre-treatment wage dynamics for all industries in Table 3 look parallel (Table 4).

Summing up, we find that the fixed exchange-rate policy adopted by Italy in the 19972000 period reduced the average real hourly wage growth in Italy for the strongest category of workers, i.e. the full-time wage earners with permanent contracts. However, the wage trajectories of public sector workers have not been affected by the policy. Indeed, the policy decreased the average real wage growth in the private sector.

The above results are also robust to the inclusion in the sample of other categories of Italian workers in paid employment, namely part-time workers and workers on temporary contracts (t.c.; see results in Table A4 and Table A5 in Appendix). However, it should be noted that the number of observations increases only by $9 \%$ (roughly 4000 obs.).

There are two complementary explanations for this small increase. First, we focus on workers in paid employment with complete 8-year work histories. Obviously, part-time workers and workers on temporary contracts are less likely to fit within this type of sample restriction. Second, these workers are not a large share of the labour force. For instance, data from the Organization for Economic Cooperation and Development (2002) suggest that the percentage of dependent employees in temporary jobs was around 5\% in both Italy and the UK in 1990, and it increased to around 7\% in the UK and $10 \%$ in Italy in 2000.

Finally, the above results are robust to the use of $\ln w_{i t}-\ln c p i_{i t}$ as dependent variable (see Table A6 in Appendix).

\section{Discussion}

An argument typically used (mostly by politicians and journalists) in favour of fixed exchange-rate regimes is that workers are more protected against losses of purchasing power due to currency devaluation and imported inflation. This paper suggests that fixed exchange rates do not necessarily provide a better protection for workers.

Looking at the big picture, our main finding is that the fixed exchange-rate policy adopted by Italy after 1996 decreased the average real wage growth in the private sector. Why has this happened? The answer to this question is not the key point of this 
paper, which is intended to provide reliable causal estimates. However, we make an attempt to answer the above question in this section. An answer can be based on two views. The first can be labeled as the "neoclassical" view. The second can be defined as the "new-Keynesian" view. Both views are based on theories of real wage determination.

\section{$\underline{\text { The neoclassical view }}$}

Following the first view, the decline of the Italian real wage growth in the private sector can be seen as the result of a new equilibrium in the private sector of tradable goods and services. As a matter of fact, the Italian current account rapidly improved when Italy left the EMS in 1992 from a deficit of $-2.4 \%$ to a surplus of $3.1 \%$ in 1996 (see Figure A1 in Appendix). However, when Italy re-joined the EMS, the current account progressively worsened, reaching a deficit of $-0.2 \%$ in 2000 , which increased to $-2.8 \%$ in 2008 .

Since we control for individual productivity characteristics in our regression models, i.e. labour-supply determinants, one channel through which the policy may have reduced wage growth is by affecting the labour-demand schedule of firms.

Less current-account surplus may have implied that the labour-demand schedule in the private sector of tradable goods and services shifted towards left as in Figure A2 in Appendix. The latter can simply be the consequence of the fact that a number of Italian firms were put out of the market by the fixation of an inappropriate parity ${ }^{7}$. The result was an equilibrium characterized by lower log real wage. As shown in Figure A3 in Appendix, a negative $\psi_{3}$ means that the policy reduced the log real wage of the treated in the treatment period.

This new equilibrium extended to the private sector as a whole since what happened in the tradable sector was not accommodated by compensating shifts in the non-tradable sector.

Thus, the fixed exchange-rate policy caused a trade shock and the labour market adjusted to a new equilibrium. These forces would be behind our findings. Since the

\footnotetext{
${ }^{7}$ In the neoclassical model, the labour-demand schedule of the market is the horizontal sum of the labourdemand schedules of each firm in the market. Thus, a reduction of the number of firms in the market shifts the labour-demand schedule of the market towards left.
} 
current account reached its positive peak in 1996, a significant effect of the treatment on the pre-treatment outcome is unlikely.

Yet, the above explanation is not convincing for three reasons. First, Italy had already been exposed to a fixed exchange-rate policy in the past - before exiting the EMS in September 1992 (see Figure 2). The current account worsened in the years between 1987 and 1992 (Figure A1) but real wage growth was sustained between 1987 and 1991 (Figure 4). Second, the neoclassical view does not take into account the specificity of the European institutional wage-bargaining setting where unions play a key role, particularly in the labour-force group that we examine. Third, we should ask ourselves what would have happened to the nominal exchange rate in Italy, had the country not joined the EMS in 1996. Since we are simulating "parallel worlds", we should look at the UK as counterfactual. As the British pound revaluated (with respect to the ecu) in the 1997-2000 period, we should assume a revaluation of the lira as the most likely scenario. In this case, by stopping the decrease of the nominal exchange rate in Figure 2, the policy may have saved a number of Italian firms rather than putting them out of the market.

\section{The new-Keynesian view}

A second possible interpretation, the new-Keynesian view, is based on the idea that the price of a good, $p$, is determined by the price-setting equation. Its level ultimately depends on the nominal wage, $w$, the real labour productivity, $a$, and the profit margin

or mark-up, $\mu$, according to the equation $p=\frac{w}{a}(1+\mu)$. The version of this equation we look at in this context is $g_{w}-g_{p} \cong g_{a}-\Delta \mu$. In this theory, real wage growth decreases when either $g_{a}$ decreases or $\Delta \mu$ increases, or both things happen.

This view puts less emphasis on trade, and more on the distributive conflict between workers and employers. In addition, the new economic environment (free capital mobility, central bank independence, and a new system of industrial relations) plays a key role.

Let us discuss the potential effects of the policy on $\Delta \mu$ and $g_{a}$ separately. 
On the one hand, the policy may have induced a decrease in $g_{a}$. Since we control for individual productivity characteristics in our regression models, one channel through which the policy may have reduced $g_{a}$ is by hurting the productivity characteristics of Italian firms.

From the firm side, one can look at $g_{a}$ as positively affected by the growth rate of the capital-labour ratio and by the growth rate of total factor productivity.

For instance, the exchange-rate stability in an environment of free capital mobility may have induced a number of Italian entrepreneurs to reallocate capital in other EMS countries where business conditions were more favourable, once the advantages of potential lira devaluation were gone. This reallocation of private capital, inducing a lower growth rate of the capital-labour ratio in the private sector, would also explain why the public sector did not experience lower real wage growth.

Unfortunately, the dataset used in this paper does not allow us to test the hypothesis that the policy actually implied a lower growth rate of the capital-labour ratio in the private sector because data on firm characteristics are not available. The same argument applies to total factor productivity.

On the one hand, the policy may have favoured an increase in $\Delta \mu$ through the elimination of the exchange-rate risk in a new environment where capital could freely circulate. Free capital mobility and absence of exchange-rate risk may have increased the average wage bargaining strength of Italian employers and, as a consequence, $\Delta \mu$ (Sen and Dutt, 1995). Some facts support this idea.

First, the wage indexation mechanism in place in Italy since the 1970s (the so-called scala mobile), which automatically adjusted nominal wage growth to actual inflation, was gradually weakened in the 1980s and completely abolished in July 1992. This mechanism was replaced by a new type of collective agreement system (the so-called protocollo d'intesa) in July 1993, based on expected inflation and sector-level bargaining between unions and employer organizations. When not involved as the employer, the government played a role of intermediation.

Second, the fixed exchange-rate policy, adopted in a new environment characterized by central bank independence, may have reduced the expected inflation. This likely 
provided private-sector employers in Italy with an argument to ask for lower nominal wage growth, and unions with a reason to agree.

Third, almost all the sector-level contracts were renewed between 1997 and 1998 (Centro di Studi Economici e Sindacali, 2000). This fact not only suggests that the policy may have affected nominal wage growth by 1997 onwards, but also that a significant effect of the treatment on the pre-treatment outcome is unlikely.

Fourth, the labour share in Italy decreased during the treatment period (see Figure A4 in Appendix). The implication is that the average mark-up increased during that period.

\section{Conclusions}

This paper has used a Difference-in-Differences estimation approach and individual data from the European Community Household Panel to provide causal evidence on the link between exchange-rate policies and labour-market outcomes. The results suggest that the fixed exchange-rate policy adopted by Italy in the 1997-2000 period has reduced the real hourly wage growth of Italian full-time workers with permanent contracts, on average, by $3 \%$. However, the cost of the policy has been ultimately paid by the private sector where real wage growth has decreased by $5.4 \%$.

The main strength of our analysis is that, to the best of our knowledge, we are the first to evaluate an exchange-rate policy choice in a quasi-experimental setting using individual data. The main limitation is that we do not additionally control for firm characteristics. However, to our knowledge, this is something that cannot be done with the existing available data.

In the last two decades, the Italian economy has been suffering for a number of reasons. This paper has concentrated on one of the possible reasons: the fixed exchange-rate policy adopted since November 1996. By lowering real wage growth, this policy may have affected consumption growth, income distribution and possibly output growth. Nevertheless, alternative explanations of the Italian decline have been documented in the literature. Further research is thus needed to investigate the relative importance of the competing explanations and to provide policy advice. 


\section{References}

Andersen, T., and Sørensen, J. (1988) "Exchange rate variability and wage formation in open economies". Economics Letters, 28(3): 263-268.

Bagnai, A. (2013) Il tramonto dell'euro. Come e perché la fine della moneta unica salverebbe democrazia e benessere in Europa (5th reprint). Rome: Imprimatur.

Bertrand, M., Duflo, E., and Mullainathan, S. (2004) "How much should we trust differences-in-differences estimates?". The Quarterly Journal of Economics, 119(1): 249-275.

Burgess, S., and Knetter, M. (1998) "An international comparison of employment adjustment to exchange rate fluctuations". Review of International Economics, 6(1): 151-63.

Campa, J., and Goldberg, L. (2001) "Employment versus wage adjustment and the U.S. dollar". The Review of Economics and Statistics, 83(3): 477-489.

Centro di Studi Economici e Sindacali (2000) Le relazioni sindacali in Italia, 19971998. Rome: Edizioni Lavoro.

Centeno, M., and Novo, Á. (2013) "Paying for others' protection: Causal evidence on wages in a two-tier system". Paper presented at the 2014 SOLE Conference, Society of Labor Economists, 2-3 May 2014, Arligton.

Collins, S., and Park, W. (1989) "Exchange rates, wages, and productivity". In: Sachs, J., and Collins, S. (eds.) Developing Country Debt and Economic Performance, Vol. 3, Chicago: The University of Chicago Press.

Daveri, F., and Jona-Lasinio, C. (2005) "Italy's decline: Getting the facts right". Giornale degli Economisti e Annali di Economia, 64(4): 365-410.

Daveri, F., and Parisi, M. F. (2010) "Experience, innovation and productivity: Empirical evidence from Italy's slowdown". CESIfo Working Papers, $\mathrm{n}^{\circ}$ 3123, CESIfo Group Munich, July.

Djajić, S. (1988) "Exchange rates, wages, and the international allocation of capital". American Economic Review, Papers \& Proceedings. 78(2): 341-345.

Dornbusch, R. (1987) "Exchange rate economics: 1986". The Economic Journal, 97(385): 1-18.

Galí, J., and Monacelli, T. (2013) "Understanding the gains from wage flexibility: The exchange rate connection". Unpublished manuscript, December.

Goldberg, L., and Tracy, J. (2000) "Exchange rates and local labor markets". In: Feenstra, R. (ed.) The Impact of International Trade on Wages, Chicago: The University of Chicago Press.

Goldberg, L., and Tracy, J. (2001) "Exchange rates and wages". NBER Working Papers, $\mathrm{n}^{\circ}$ 8137, National Bureau of Economic Research, February. 
Goldstein, M. (1974) "The effect of exchange rate changes on wages and prices in the United Kingdom: An empirical study". IMF Staff Papers, 21(3): 694-739.

Hassan, F., and Ottaviano, G. (2013) "Productivity in Italy: The great unlearning". Available at http://www.voxeu.org, 30 November 2013.

Lawler, P. (2000) "Union wage setting and exchange rate policy". Economica, 67(265): 91-100.

Lechner, M. (2008) "A note on endogenous control variables in causal studies". Statistics \& Probability Letters, 78(2): 190-195.

Lippi, F., and Schivardi, F. (2014) "L'insostenibile pesantezza dell'euro". Available at http://www.lavoce.info, 11 Aprile 2014.

Manasse, P. (2013) "The roots of Italian stagnation". CEPR Policy Insight, n 66, Centre for Economic Policy Research, June.

Manasse, P., Nannicini, T., and Saia, A. (2013) Euro sì, euro no. Gli effetti della moneta unica sull'economia italiana. LinkTank, e-book downloadable at http://www.linkiesta.it/effetti-euro-italia

Mishra, P., and Spilimbergo, A. (2011) "Exchange rates and wages in an integrated world". American Economic Journal: Macroeconomics, 3(4): 53-84.

Nannicini, T. (2013a) "Euro, domanda, e produttività: un viaggio nel mito. Parte 1". Available at http://noisefromamerika.org, 10 August 2013.

Nannicini, T. (2013b) "Euro, domanda, e produttività: un viaggio nel mito. Parte 2". Available at http://noisefromamerika.org, 16 August 2013.

Organization for Economic Cooperation and Development (2002) OECD Employment Outlook (Chapter 3), Paris: OECD.

Pellegrino, B., and Zingales, L. (2014) "Diagnosing the Italian disease". Unpublished manuscript, September.

Sachs, J. (1980) "Wages, flexible exchange rates, and macroeconomic policy". The Quarterly Journal of Economics, 94(4): 731-747.

Sen, A., and Dutt, A. (1995) "Wage bargaining, imperfect competition, and the markup: Optimizing microfoundations". Economics Letters, 48( 1): 15-20.

Schmitt-Grohé, S., and Uribe, M. (2012) "Managing currency pegs". American Economic Review, Papers \& Proceedings, 102(3): 192-197.

Schmitt-Grohé, S., and Uribe, M. (2013) "Downward nominal wage rigidity, currency pegs, and involuntary unemployment". Unpublished manuscript, August.

Spinanger, D. (1999) "Textiles beyond the MFA phase-out". The World Economy, 22(4): 455-476. 
Wright, P., and Bastos, P. (2012) "Exchange rates and wages in unionized labor markets". Industrial and Labor Relations Review, 65(4): 975-999. 
Fig. 1 - The Italian productivity slowdown

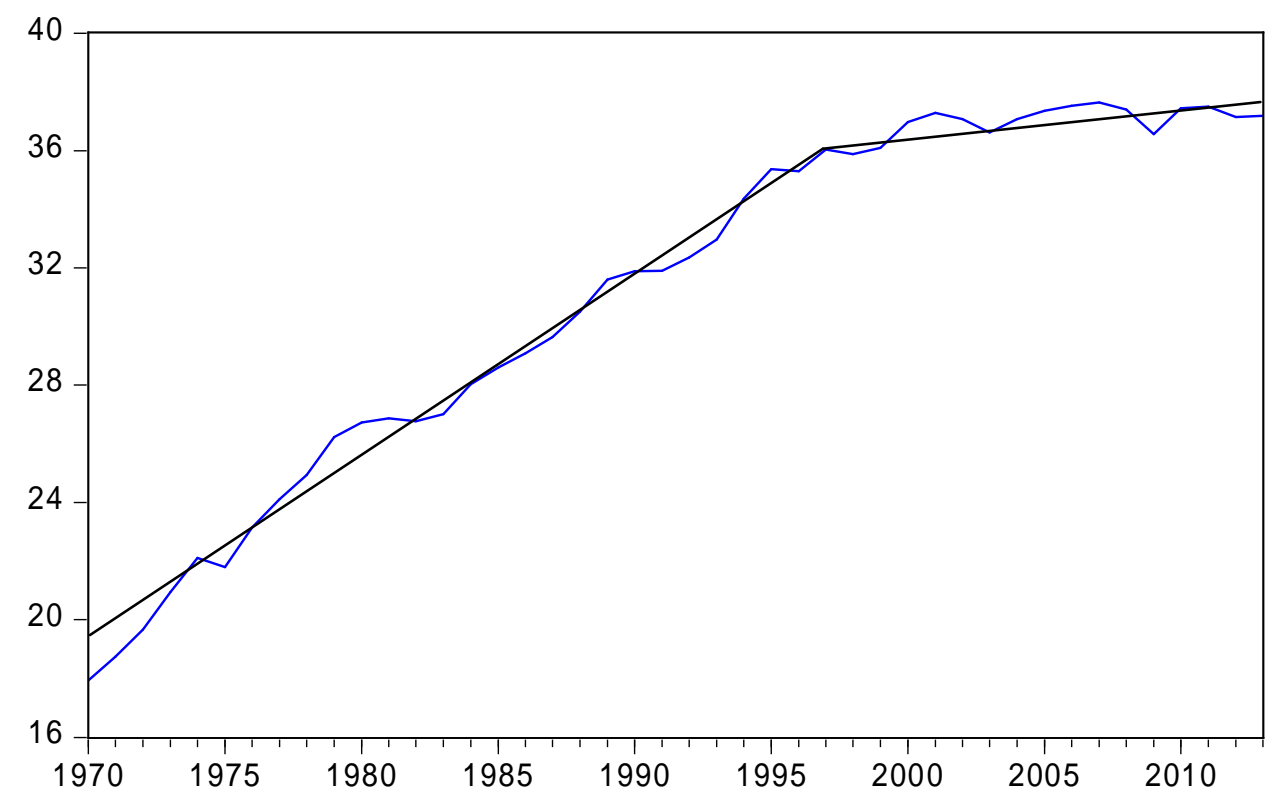

Italy GDP per hour worked, USD, constant prices, 2005 PPPs

Source: OECD.Stat (http://stats.oecd.org/) 
Fig. 2 - Nominal exchange rate between Italian liras and ecu

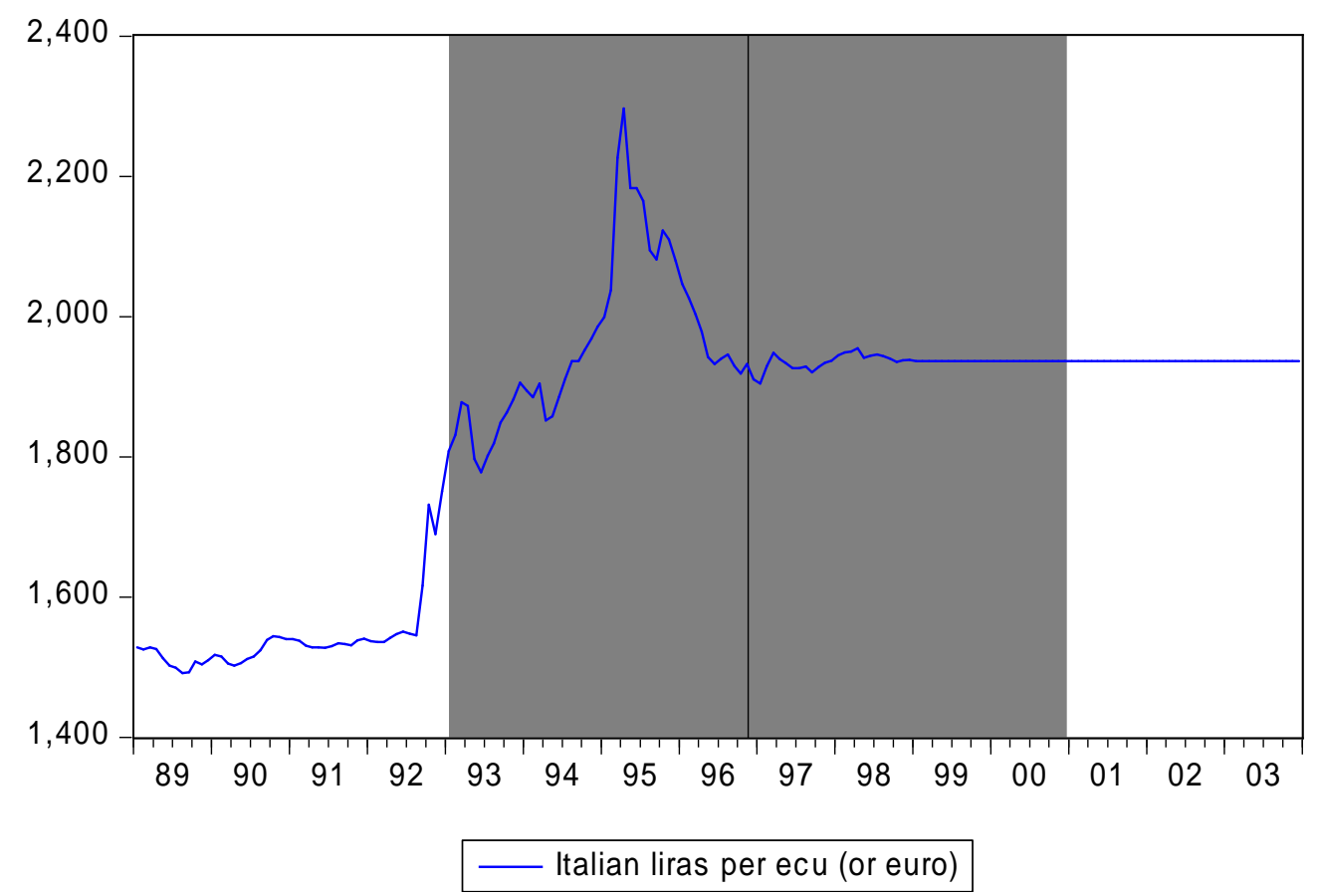

Source: Eurostat (http://epp.eurostat.ec.europa.eu/portal/page/portal/statistics/) 
Fig. 3 - Italy vs. UK productivity

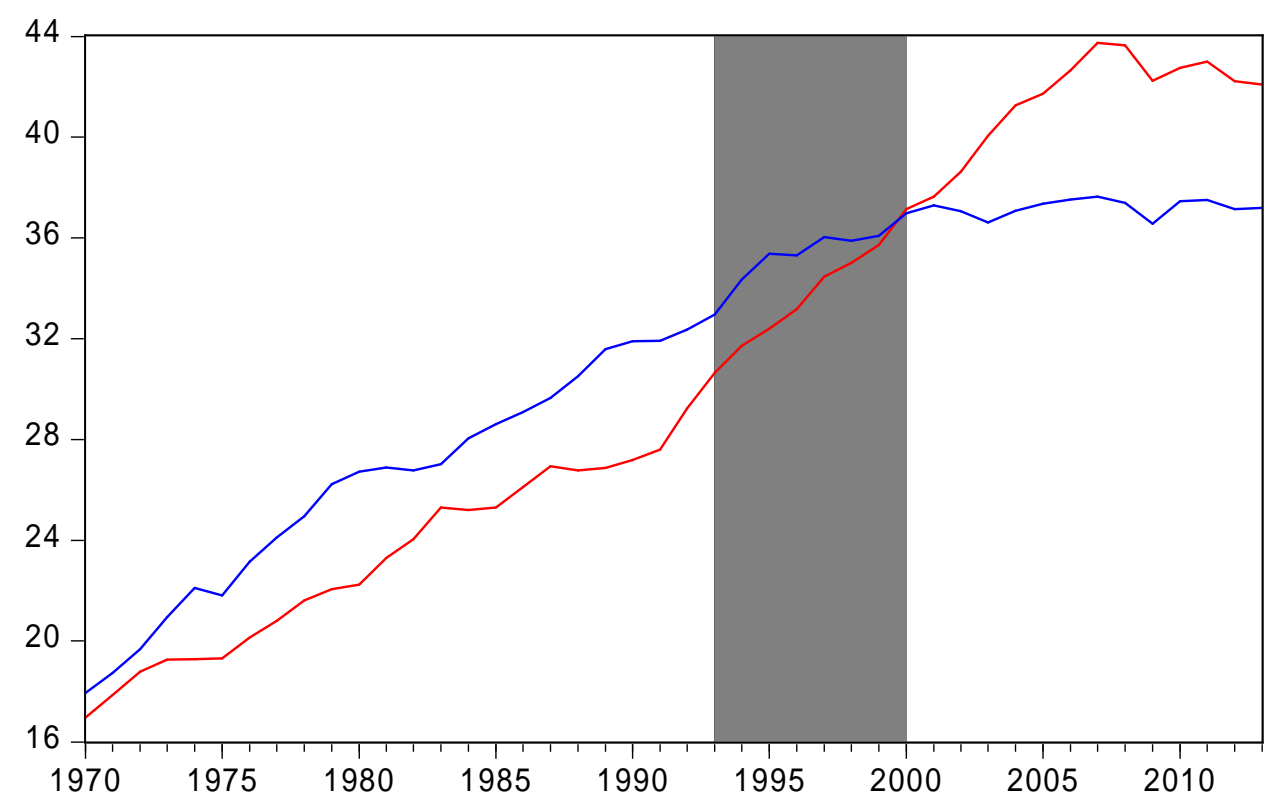

UK GDP per hour worked, USD, constant prices, 2005 PPPs Italy GDP per hour worked, USD, constant prices, 2005 PPPs

Source: OECD.Stat (http://stats.oecd.org/) 
Fig. 4 - Italy vs. UK real wage

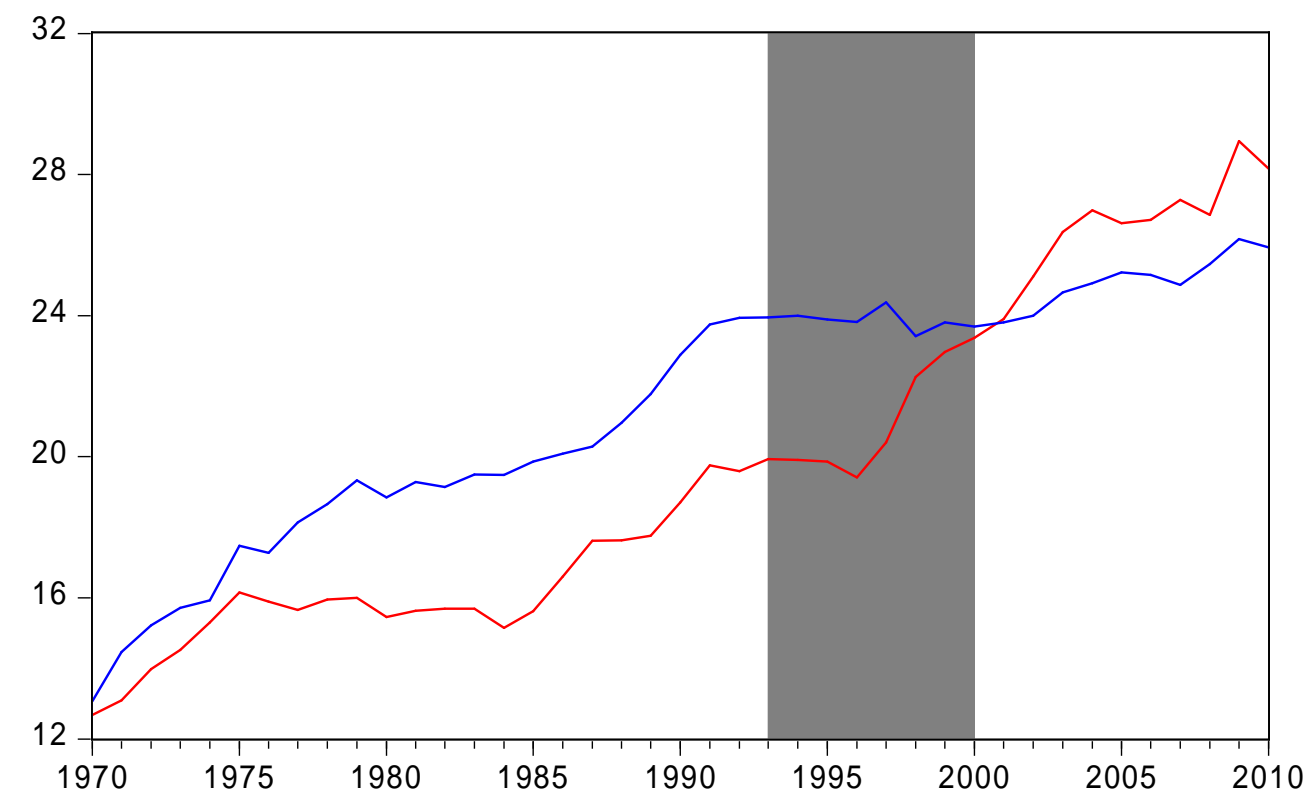

UK real wage per hour worked, USD, constant prices, 2005 PPPs Italy real wage per hour worked, USD, constant prices, 2005 PPPs

Source: Author elaboration from OECD. Stat and Eurostat data 
Table 1. Treatment effect, 1997-2000, full-time workers on p.c.

(Dependent variable: lnw)

\begin{tabular}{|c|c|c|c|c|c|}
\hline & $\begin{array}{c}\text { All } \\
\text { sectors }\end{array}$ & $\begin{array}{l}\text { Public } \\
\text { sector }\end{array}$ & $\begin{array}{l}\text { Private } \\
\text { sector }\end{array}$ & $\begin{array}{c}\text { Private } \\
\text { industry }\end{array}$ & $\begin{array}{l}\text { Private } \\
\text { services }\end{array}$ \\
\hline \multirow[t]{2}{*}{ treat } & $20.905 * * *$ & $0.927 * * *$ & $0.901 * * *$ & $0.834 * * *$ & $0.963 * * *$ \\
\hline & $(0.00646)$ & $(0.0106)$ & $(0.00803)$ & $(0.0102)$ & $(0.0125)$ \\
\hline after & (0.00699) & $(0.0115)$ & $(0.00858)$ & $(0.0114)$ & $(0.0125)$ \\
\hline \multirow[t]{2}{*}{ treat $\times$ after } & $-0.0305 * * *$ & 0.0170 & $-0.0546 * * *$ & $-0.0537 * * *$ & $-0.0656 * * *$ \\
\hline & $(0.00718)$ & $(0.0118)$ & $(0.00883)$ & $(0.0117)$ & $(0.0130)$ \\
\hline \multirow[t]{2}{*}{ age } & $0.0472 * * *$ & $0.0263 * * *$ & $0.0538 * * *$ & $0.0417 * * *$ & $0.0641 * * *$ \\
\hline & $(0.00125)$ & $(0.00236)$ & $(0.00156)$ & (0.00197) & $(0.00241)$ \\
\hline \multirow[t]{2}{*}{ age 2} & $-0.000499 * * *$ & $-0.000243 * * *$ & $-0.000591 * * *$ & $-0.000441 * * *$ & $-0.000725 * * *$ \\
\hline & $(1.53 \mathrm{e}-05)$ & $(2.73 e-05)$ & $(1.95 \mathrm{e}-05)$ & $(2.45 \mathrm{e}-05)$ & (3.06e-05) \\
\hline educ2 & $0.0740 * * *$ & $0.0726 * * *$ & $0.0701 * * *$ & $0.0787 * * *$ & $0.0500 * * *$ \\
\hline married & $(0.00392)$ & (0.00619) & $(0.00496)$ & $(0.00631)$ & $(0.00744)$ \\
\hline \multirow[t]{2}{*}{ female } & $-0.147 * * *$ & $-0.0941 * * *$ & $-0.175^{* * *}$ & $-0.166 * * *$ & $-0.180 * * *$ \\
\hline & $(0.00354)$ & $(0.00532)$ & $(0.00471)$ & $(0.00627)$ & $(0.00684)$ \\
\hline \multirow[t]{2}{*}{ supervisor } & $0.168 * * *$ & $0.160 * * *$ & $0.175 * * *$ & $0.185 * * *$ & $0.186^{* * *}$ \\
\hline & $(0.00617)$ & $(0.00950)$ & $(0.00794)$ & $(0.00996)$ & $(0.0118)$ \\
\hline \multirow[t]{2}{*}{ intermediate } & $0.0565 * * *$ & $0.0631 * * *$ & $0.0536 * * *$ & $0.0645 * * *$ & $0.0477 * * *$ \\
\hline & $(0.00420)$ & $(0.00640)$ & $(0.00544)$ & $(0.00685)$ & $(0.00830)$ \\
\hline \multirow[t]{2}{*}{ public } & $0.106 * * *$ & & & & \\
\hline & (0.00404) & & & & \\
\hline \multirow[t]{2}{*}{ disability } & $-0.0388 * * *$ & $-0.0285^{* * *}$ & $-0.0431 * * *$ & $-0.0259 * * *$ & $-0.0617 * * *$ \\
\hline & $(0.00523)$ & $(0.00749)$ & $(0.00682)$ & $(0.00890)$ & $(0.00997)$ \\
\hline \multirow[t]{2}{*}{ _Iocc2 } & $0.437 * * *$ & $0.404 * * *$ & $0.444 * * *$ & $0.348 * * *$ & $0.511 * * *$ \\
\hline & $(0.00850)$ & $(0.0110)$ & $(0.0131)$ & $(0.0185)$ & $(0.0184)$ \\
\hline _Iocc3 & $0.278 * * *$ & $0.259 * * *$ & $0.284 * * *$ & $0.212 * * *$ & $0.338 * * *$ \\
\hline & $(0.00740)$ & $(0.00995)$ & $(0.0101)$ & $(0.0137)$ & $(0.0145)$ \\
\hline _Iocc4 & $0.186 * * *$ & $0.120 * * *$ & $0.231 * * *$ & $0.165 * * *$ & $0.282 * * *$ \\
\hline & $(0.00651)$ & $(0.00861)$ & $(0.00873)$ & $(0.0119)$ & $(0.0128)$ \\
\hline _Iocc5 & $0.0231 * * *$ & $0.124 * * *$ & $-0.0214 * *$ & $0.0716 * *$ & 0.00513 \\
\hline & $(0.00771)$ & $(0.0111)$ & $(0.0100)$ & $(0.0282)$ & $(0.0127)$ \\
\hline _Iocc6 & 0.000144 & 0.0308 & -0.00997 & $-0.182 * * *$ & -0.0177 \\
\hline & $(0.0189)$ & $(0.0299)$ & $(0.0237)$ & $(0.0484)$ & $(0.0562)$ \\
\hline _Iocc7 & $0.0778 * * *$ & $0.101 * * *$ & $0.0777 * * *$ & $0.0564 * * *$ & $0.0940 * * *$ \\
\hline & $(0.00655)$ & $(0.0121)$ & $(0.00799)$ & $(0.0103)$ & $(0.0147)$ \\
\hline _Iocc8 & $0.0910 * * *$ & $0.138 * * *$ & $0.0850 * * *$ & $0.0589 * * *$ & $0.0932 * * *$ \\
\hline & $(0.00710)$ & $(0.0126)$ & $(0.00866)$ & $(0.0111)$ & $(0.0145)$ \\
\hline Constant & $-3.840 * * *$ & $-2.850 * * *$ & $-4.192 * * *$ & $-3.463 * * *$ & $-4.593 * * *$ \\
\hline & $(0.242)$ & $(0.367)$ & $(0.313)$ & $(0.374)$ & $(0.512)$ \\
\hline Obs. & 43,291 & 14,239 & 29,052 & 13,644 & 14,900 \\
\hline R-squared & 0.679 & 0.699 & 0.644 & 0.654 & 0.643 \\
\hline
\end{tabular}

Robust standard errors in parentheses

$* * * \mathrm{p}<0.01, * * \mathrm{p}<0.05, * \mathrm{p}<0.1$ 
Table 2. Parallel trends, 1993-1996, full-time workers on p.c.

(Dependent variable: $\operatorname{lnw}$ )

\begin{tabular}{|c|c|c|c|c|c|}
\hline & $\begin{array}{c}\text { All } \\
\text { sectors }\end{array}$ & $\begin{array}{l}\text { Public } \\
\text { sector }\end{array}$ & $\begin{array}{l}\text { Private } \\
\text { sector }\end{array}$ & $\begin{array}{l}\text { Private } \\
\text { industry }\end{array}$ & $\begin{array}{c}\text { Private } \\
\text { services }\end{array}$ \\
\hline treat & $\begin{array}{l}-37.49 \\
(34.87)\end{array}$ & $\begin{array}{l}-93.08^{*} \\
(54.27)\end{array}$ & $\begin{array}{c}8.103 \\
(44.63)\end{array}$ & $\begin{array}{c}-12.29 \\
(53.84)\end{array}$ & $\begin{array}{c}20.40 \\
(74.86)\end{array}$ \\
\hline time & $\begin{array}{c}0.0471 * * \\
(0.0214)\end{array}$ & $\begin{array}{c}0.0708 * * \\
(0.0331)\end{array}$ & $\begin{array}{c}0.0235 \\
(0.0274)\end{array}$ & $\begin{array}{c}0.0371 \\
(0.0327)\end{array}$ & $\begin{array}{c}0.0198 \\
(0.0465)\end{array}$ \\
\hline treat $\times$ time & $\begin{array}{c}0.0192 \\
(0.0175)\end{array}$ & $\begin{array}{l}0.0470 * \\
(0.0272)\end{array}$ & $\begin{array}{c}-0.00363 \\
(0.0223)\end{array}$ & $\begin{array}{l}0.00655 \\
(0.0270)\end{array}$ & $\begin{array}{r}-0.00976 \\
(0.0375)\end{array}$ \\
\hline Constant & $\begin{array}{c}-90.15 * * \\
(39.33)\end{array}$ & $\begin{array}{c}-131.6^{* *} \\
(60.95)\end{array}$ & $\begin{array}{l}-47.65 \\
(50.42)\end{array}$ & $\begin{array}{l}-72.59 \\
(60.25)\end{array}$ & $\begin{array}{l}-40.93 \\
(85.40)\end{array}$ \\
\hline $\begin{array}{l}\text { Obs. } \\
\text { R-squared }\end{array}$ & $\begin{array}{c}19,846 \\
0.674\end{array}$ & $\begin{array}{l}6,696 \\
0.683\end{array}$ & $\begin{array}{c}13,150 \\
0.641\end{array}$ & $\begin{array}{l}6,522 \\
0.658\end{array}$ & $\begin{array}{l}6,409 \\
0.640\end{array}$ \\
\hline
\end{tabular}

Regressions control for all model covariates Robust standard errors in parentheses $* * * \mathrm{p}<0.01, * * \mathrm{p}<0.05, * \mathrm{p}<0.1$ 
Table 3. Treatment effect, 1997-2000, private sector full-time workers on p.c.

(Dependent variable: lnw)

\begin{tabular}{|c|c|c|c|c|c|c|c|c|c|c|c|}
\hline & agf & mut & con & mnf & com & hor & tra & fin & rer & edu & hlt \\
\hline \multirow[t]{2}{*}{ treat } & $1.154 * * *$ & $0.758 * * *$ & $0.875 * * *$ & 0.838*** & (0.994*** & $1.236 * * *$ & $0.903 * * *$ & $0.903 * * *$ & $0.820 * * *$ & $1.067 * * *$ & $1.083 * * *$ \\
\hline & $(0.0767)$ & $(0.0504)$ & $(0.0311)$ & $(0.0110)$ & $(0.0206)$ & $(0.0471)$ & $(0.0328)$ & $(0.0351)$ & $(0.0329)$ & $(0.0881)$ & $(0.0400)$ \\
\hline \multirow[t]{2}{*}{ after } & $0.193 * *$ & 0.0693 & $0.133 * * *$ & $0.0722 * * *$ & $0.0458 * *$ & $0.0834 *$ & 0.0154 & 0.0265 & $0.0674 * *$ & 0.0885 & $0.104 * * *$ \\
\hline & $(0.0914)$ & $(0.0505)$ & $(0.0323)$ & $(0.0124)$ & $(0.0217)$ & $(0.0465)$ & $(0.0324)$ & $(0.0320)$ & $(0.0295)$ & $(0.0695)$ & $(0.0381)$ \\
\hline \multirow[t]{2}{*}{ treat $\times$ after } & $-0.174 *$ & -0.0492 & $-0.120 * * *$ & $-0.0487 * * *$ & $-0.0414 *$ & $-0.110 * *$ & -0.0455 & $-0.0616^{*}$ & $-0.0882 * * *$ & -0.109 & $-0.124 * * *$ \\
\hline & $(0.0905)$ & $(0.0524)$ & $(0.0339)$ & $(0.0127)$ & $(0.0222)$ & $(0.0482)$ & $(0.0345)$ & $(0.0328)$ & $(0.0313)$ & $(0.0776)$ & $(0.0431)$ \\
\hline \multirow[t]{2}{*}{ lncpi } & 0.598 & 0.722 & $0.933 * * *$ & $1.020 * * *$ & $1.051 * * *$ & $1.432 * * *$ & $1.310 * * *$ & $1.433 * * *$ & $1.171 * * *$ & 1.136 & $0.757 * *$ \\
\hline & $(0.444)$ & $(0.456)$ & $(0.219)$ & $(0.0951)$ & $(0.204)$ & $(0.467)$ & $(0.323)$ & (0.309) & $(0.313)$ & $(0.800)$ & $(0.334)$ \\
\hline Constant & $\begin{array}{l}-1.837 \\
(1.922)\end{array}$ & $\begin{array}{l}-3.042 \\
(1.984)\end{array}$ & $\begin{array}{c}-3.651 * * * \\
(0.953)\end{array}$ & $\begin{array}{c}-3.573 * * * \\
(0.411)\end{array}$ & $\begin{array}{c}-4.356 * * * \\
(0.879)\end{array}$ & $\begin{array}{c}-5.392 * * * \\
(1.997)\end{array}$ & $\begin{array}{c}-4.902 * * * \\
(1.399)\end{array}$ & $\begin{array}{c}-5.332 * * * \\
(1.335)\end{array}$ & $\begin{array}{c}-5.395 * * * \\
(1.361)\end{array}$ & $\begin{array}{l}-5.197 \\
(3.522)\end{array}$ & $\begin{array}{c}-2.962 * * \\
(1.451)\end{array}$ \\
\hline Obs. & 508 & 722 & 1,929 & 10,993 & 4,254 & 987 & 1,947 & 1,908 & 2,493 & 411 & 1,144 \\
\hline $\mathrm{R}$-squared & 0.623 & 0.684 & 0.632 & 0.663 & 0.680 & 0.756 & 0.632 & 0.667 & 0.560 & 0.659 & 0.759 \\
\hline
\end{tabular}

Regressions control for all model covariates

Robust standard errors in parentheses

$$
* * * \mathrm{p}<0.01, * * \mathrm{p}<0.05, * \mathrm{p}<0.1
$$


Table 4. Parallel trends, 1993-1996, private sector full-time workers on p.c. (Dependent variable: $\operatorname{lnw}$ )

\begin{tabular}{|c|c|c|c|c|c|c|c|c|c|c|c|}
\hline & agf & mut & con & $\mathrm{mnf}$ & com & hor & tra & fin & rer & edu & htl \\
\hline treat & $\begin{array}{c}486.8 \\
(353.8)\end{array}$ & $\begin{array}{l}-176.9 \\
(284.5)\end{array}$ & $\begin{array}{l}-94.06 \\
(141.0)\end{array}$ & $\begin{array}{c}21.73 \\
(58.84)\end{array}$ & $\begin{array}{c}-5.881 \\
(122.5)\end{array}$ & $\begin{array}{c}-127.8 \\
(319.6)\end{array}$ & $\begin{array}{c}230.5 \\
(205.9)\end{array}$ & $\begin{array}{c}45.82 \\
(199.6)\end{array}$ & $\begin{array}{c}42.75 \\
(216.8)\end{array}$ & $\begin{array}{c}-63.05 \\
(657.5)\end{array}$ & $\begin{array}{c}-123.7 \\
(203.9)\end{array}$ \\
\hline time & $\begin{array}{c}-0.148 \\
(0.212)\end{array}$ & $\begin{array}{c}0.118 \\
(0.179)\end{array}$ & $\begin{array}{c}0.148^{*} \\
(0.0843)\end{array}$ & $\begin{array}{c}0.0193 \\
(0.0358)\end{array}$ & $\begin{array}{c}0.0194 \\
(0.0776)\end{array}$ & $\begin{array}{l}0.0870 \\
(0.195)\end{array}$ & $\begin{array}{c}-0.104 \\
(0.128)\end{array}$ & $\begin{array}{r}-0.0185 \\
(0.124)\end{array}$ & $\begin{array}{c}0.0773 \\
(0.136)\end{array}$ & $\begin{array}{l}0.0433 \\
(0.418)\end{array}$ & $\begin{array}{l}0.224 * \\
(0.121)\end{array}$ \\
\hline treat $\times$ time & $\begin{array}{c}-0.243 \\
(0.177)\end{array}$ & $\begin{array}{l}0.0899 \\
(0.142)\end{array}$ & $\begin{array}{c}0.0475 \\
(0.0706)\end{array}$ & $\begin{array}{c}-0.0105 \\
(0.0295)\end{array}$ & $\begin{array}{l}0.00342 \\
(0.0613)\end{array}$ & $\begin{array}{l}0.0645 \\
(0.160)\end{array}$ & $\begin{array}{c}-0.115 \\
(0.103)\end{array}$ & $\begin{array}{l}-0.0225 \\
(0.0999)\end{array}$ & $\begin{array}{r}-0.0211 \\
(0.109)\end{array}$ & $\begin{array}{l}0.0322 \\
(0.329)\end{array}$ & $\begin{array}{l}0.0623 \\
(0.102)\end{array}$ \\
\hline Constant & $\begin{array}{c}260.9 \\
(397.4)\end{array}$ & $\begin{array}{c}-220.3 \\
(328.9)\end{array}$ & $\begin{array}{c}-278.5^{*} \\
(155.8)\end{array}$ & $\begin{array}{c}-40.39 \\
(65.90)\end{array}$ & $\begin{array}{c}-39.98 \\
(142.4)\end{array}$ & $\begin{array}{c}-163.4 \\
(358.1)\end{array}$ & $\begin{array}{c}186.1 \\
(234.6)\end{array}$ & $\begin{array}{c}30.12 \\
(226.7)\end{array}$ & $\begin{array}{c}-149.1 \\
(249.9)\end{array}$ & $\begin{array}{c}-85.68 \\
(763.8)\end{array}$ & $\begin{array}{l}-419.9^{*} \\
(222.1)\end{array}$ \\
\hline $\begin{array}{l}\text { Obs. } \\
\text { R-squared }\end{array}$ & $\begin{array}{c}219 \\
0.585\end{array}$ & $\begin{array}{c}370 \\
0.706\end{array}$ & $\begin{array}{c}873 \\
0.643\end{array}$ & $\begin{array}{l}5,279 \\
0.668\end{array}$ & $\begin{array}{l}1,917 \\
0.675\end{array}$ & $\begin{array}{c}390 \\
0.725\end{array}$ & $\begin{array}{c}782 \\
0.646\end{array}$ & $\begin{array}{c}892 \\
0.678\end{array}$ & $\begin{array}{l}1,000 \\
0.535\end{array}$ & $\begin{array}{c}154 \\
0.703\end{array}$ & $\begin{array}{c}496 \\
0.783\end{array}$ \\
\hline
\end{tabular}

Regressions control for all model covariates

Robust standard errors in parentheses

$* * * \mathrm{p}<0.01, * * \mathrm{p}<0.05, * \mathrm{p}<0.1$ 
Appendix 
Fig. A1 - Current account, Italy

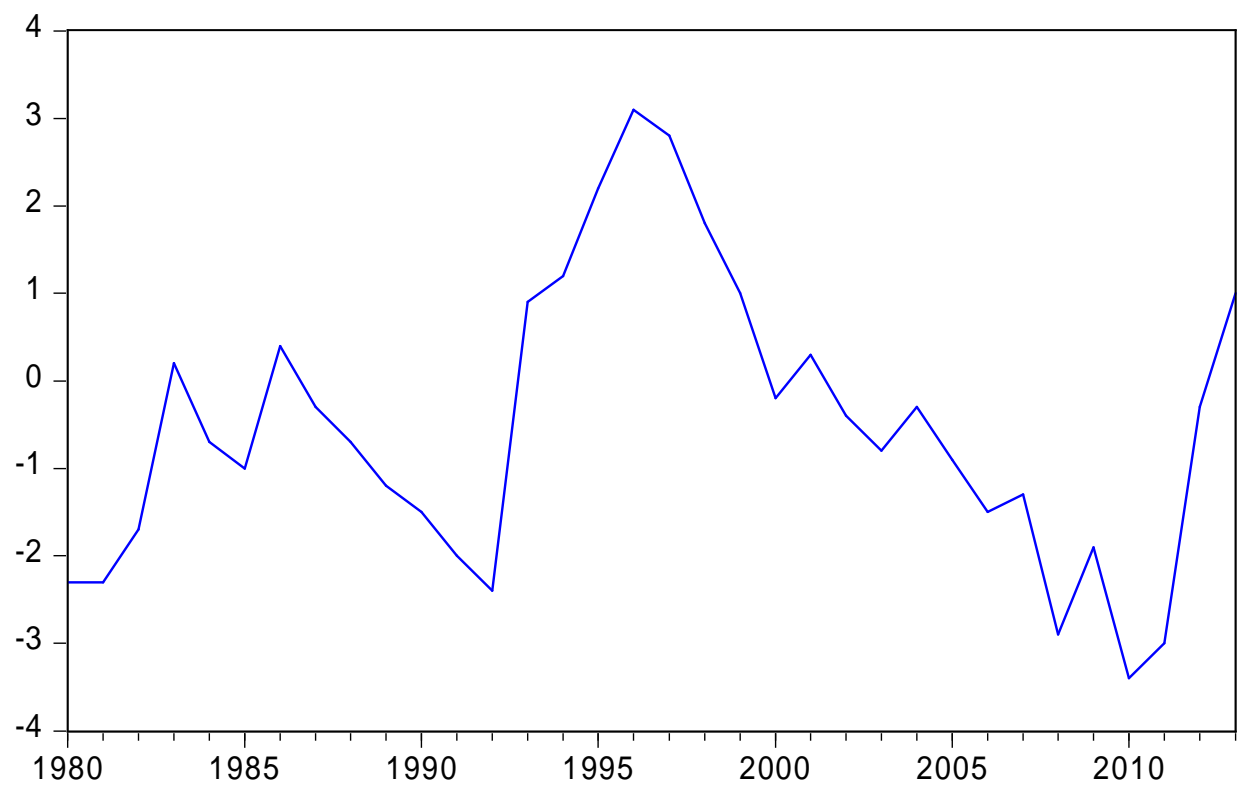

Source: Eurostat (http://epp.eurostat.ec.europa.eu/portal/page/portal/statistics/) 
Fig. A2 - The neoclassical view, private sector

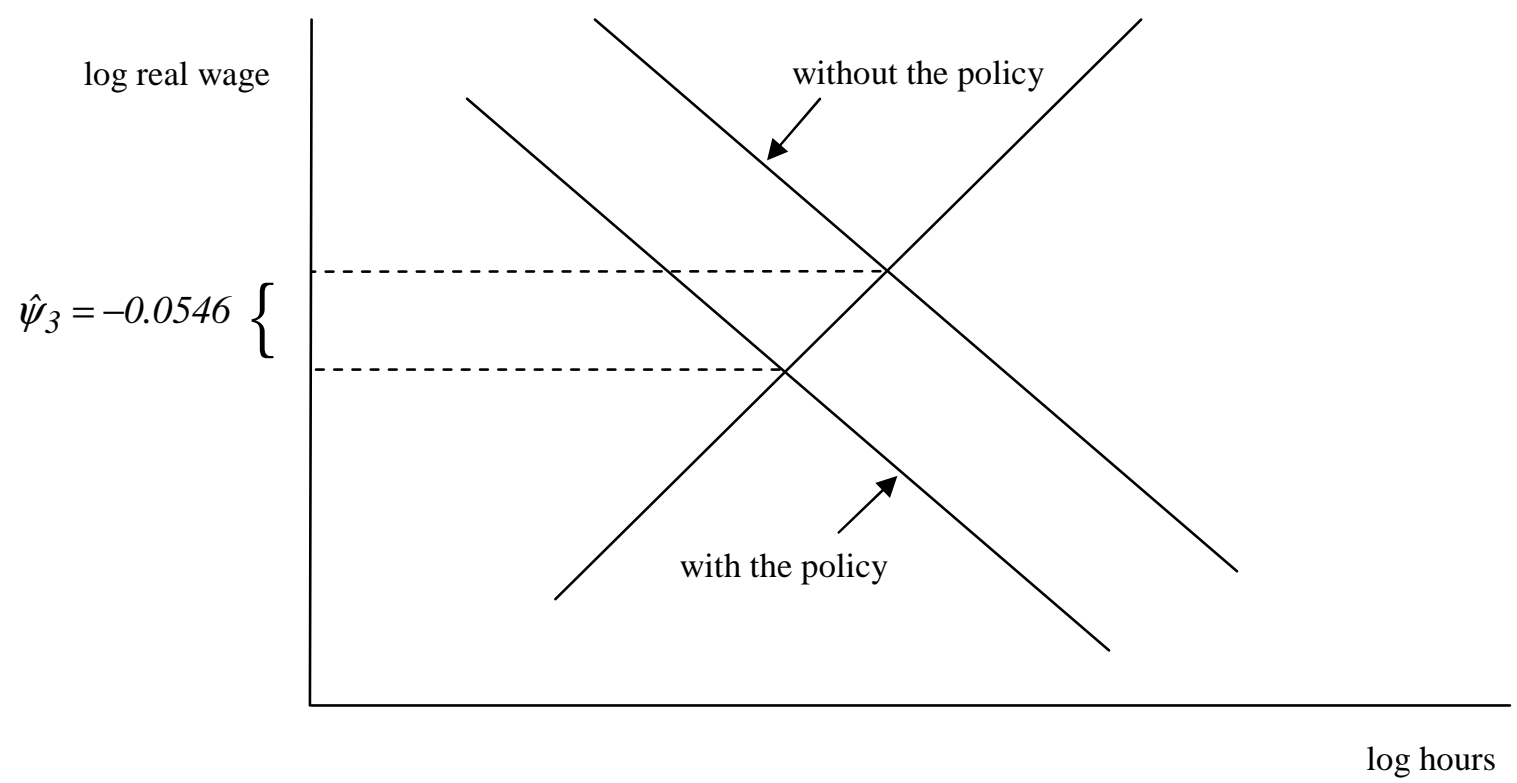


Fig. A3 - Difference-in-differences, private sector

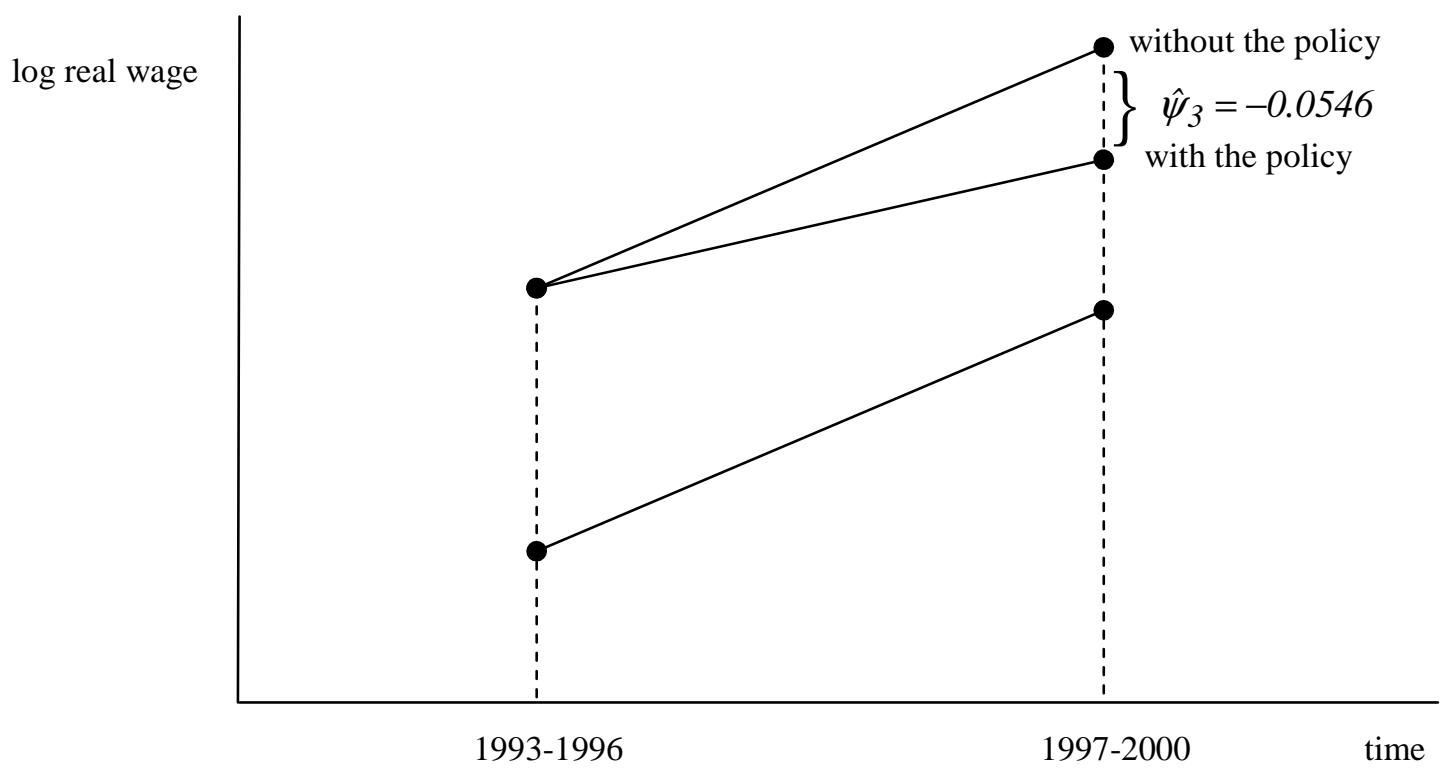


Fig. A4 - Labour share, Italy

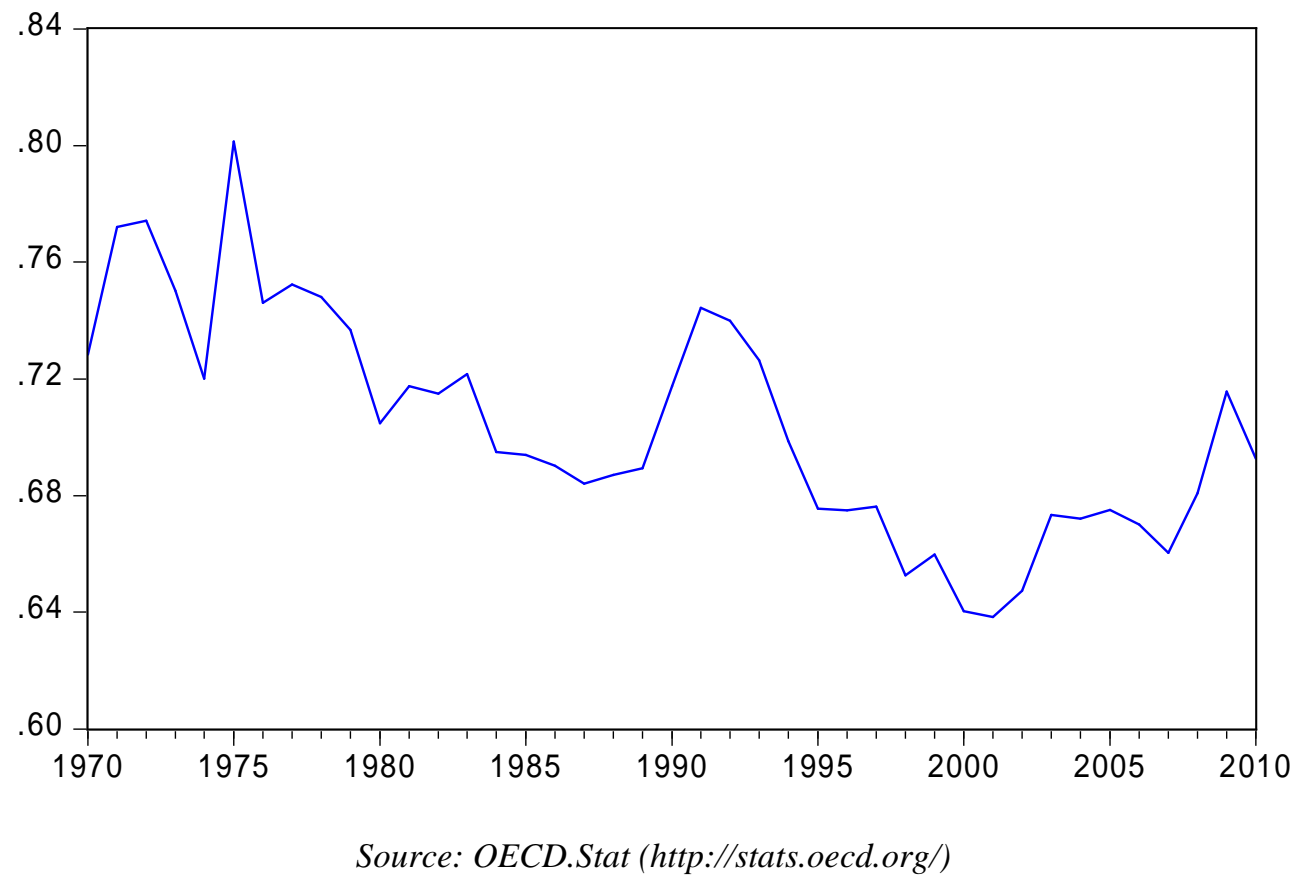


Table A1. Summary statistics for British full-time workers on p.c. (controls)

\begin{tabular}{lcccc}
\hline & mean & sd & min & max \\
\hline Inw & 1.95 & 0.51 & -2.1 & 5 \\
age & 38.41 & 11.38 & 17.0 & 65 \\
educ1 & 0.36 & 0.48 & 0.0 & 1 \\
educ2 & 0.14 & 0.34 & 0.0 & 1 \\
educ3 & 0.50 & 0.50 & 0.0 & 1 \\
married & 0.59 & 0.49 & 0.0 & 1 \\
female & 0.41 & 0.49 & 0.0 & 1 \\
supervisor & 0.26 & 0.44 & 0.0 & 1 \\
intermediate & 0.18 & 0.38 & 0.0 & 1 \\
nonsupervisor & 0.56 & 0.50 & 0.0 & 1 \\
public & 0.25 & 0.43 & 0.0 & 1 \\
disability & 0.26 & 0.44 & 0.0 & 1 \\
agriculture & 0.01 & 0.08 & 0.0 & 1 \\
industry & 0.30 & 0.46 & 0.0 & 1 \\
services & 0.69 & 0.46 & 0.0 & 1 \\
immigrant & 0.00 & 0.07 & 0.0 & 1 \\
_Iocc1 & 0.18 & 0.38 & 0.0 & 1 \\
_Iocc2 & 0.13 & 0.34 & 0.0 & 1 \\
_Iocc3 & 0.14 & 0.34 & 0.0 & 1 \\
_Iocc4 & 0.17 & 0.37 & 0.0 & 1 \\
_Iocc5 & 0.11 & 0.32 & 0.0 & \\
_Iocc6 & 0.01 & 0.08 & 0.0 & \\
_Iocc7 & 0.12 & 0.32 & 0.0 & \\
_Iocc8 & 0.10 & 0.29 & 0.0 & \\
_Iocc9 & 0.05 & 0.22 & 0.0 & \\
\hline Observations & 17355 & & & 1 \\
\hline
\end{tabular}

Nominal wages are measured in British pounds 
Table A2. Summary statistics for Italian full-time workers on p.c. (treated)

\begin{tabular}{lcccc}
\hline & mean & sd & $\min$ & $\max$ \\
\hline Inw & 2.72 & 0.38 & -0.2 & 5 \\
age & 39.59 & 10.23 & 17.0 & 65 \\
educ1 & 0.40 & 0.49 & 0.0 & 1 \\
educ2 & 0.48 & 0.50 & 0.0 & 1 \\
educ3 & 0.12 & 0.33 & 0.0 & 1 \\
married & 0.71 & 0.46 & 0.0 & 1 \\
female & 0.37 & 0.48 & 0.0 & 1 \\
supervisor & 0.09 & 0.29 & 0.0 & 1 \\
intermediate & 0.17 & 0.38 & 0.0 & 1 \\
nonsupervisor & 0.74 & 0.44 & 0.0 & 1 \\
public & 0.38 & 0.49 & 0.0 & 1 \\
disability & 0.06 & 0.24 & 0.0 & 1 \\
agriculture & 0.02 & 0.14 & 0.0 & 1 \\
industry & 0.35 & 0.48 & 0.0 & 1 \\
services & 0.63 & 0.48 & 0.0 & 1 \\
immigrant & 0.02 & 0.15 & 0.0 & 1 \\
_Iocc1 & 0.02 & 0.15 & 0.0 & 1 \\
_Iocc2 & 0.11 & 0.31 & 0.0 & 1 \\
_Iocc3 & 0.13 & 0.33 & 0.0 & 1 \\
_Iocc4 & 0.26 & 0.44 & 0.0 & 1 \\
_Iocc5 & 0.09 & 0.29 & 0.0 & \\
_Iocc6 & 0.01 & 0.10 & 0.0 & \\
_Iocc7 & 0.19 & 0.39 & 0.0 & 0.0 \\
_Iocc8 & 0.09 & 0.29 & 0.0 & \\
_Iocc9 & 0.09 & 0.29 & & 1 \\
\hline Observations & 25936 & & & 1 \\
\hline
\end{tabular}

Nominal wages are measured in Italian liras 
Table A3. Industry labels

\begin{tabular}{cl}
\hline Abbreviation & Industry denomination \\
\hline agf & Agriculture, hunting and forestry + Fishing \\
mut & Mining + Electricity, gas and water supply \\
mnf & Construction \\
com & Manufacturing \\
hor & Wholesale and retail commerce and repair activities \\
tra & Hotels and restaurants \\
fin & Transportation, storage and communication \\
rer & Financial intermediation \\
edu & Real estate, renting and business activities \\
htl & Education \\
\hline
\end{tabular}


Table A4. Treatment effect, 1997-2000, including part-time workers and workers on t.c.

(Dependent variable: lnw)

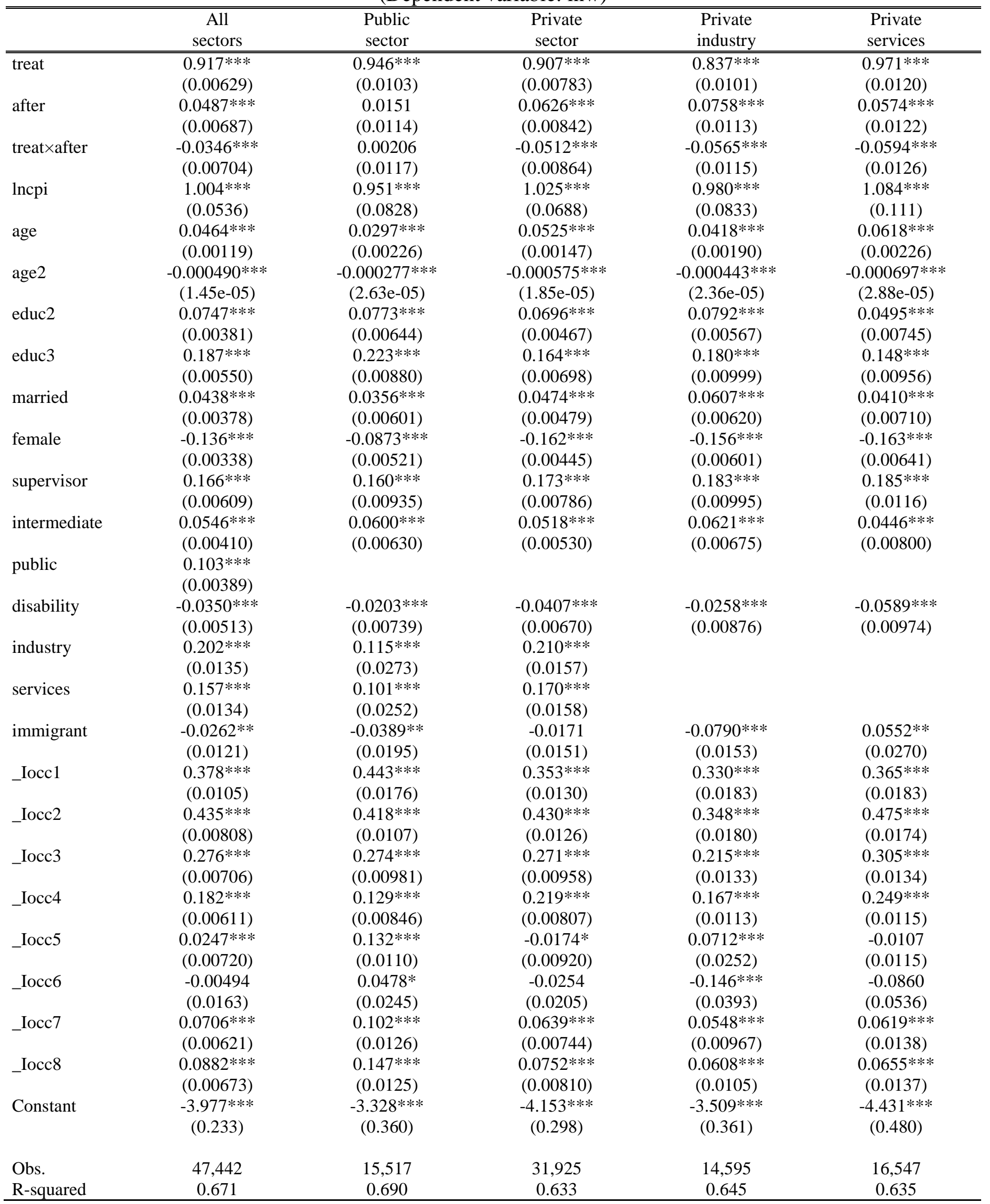

Robust standard errors in parentheses $* * * \mathrm{p}<0.01, * * \mathrm{p}<0.05, * \mathrm{p}<0.1$ 
Table A5. Parallel trends, 1993-1996, including part-time workers and workers on t.c. (Dependent variable: $\ln w)$

\begin{tabular}{|c|c|c|c|c|c|}
\hline & $\begin{array}{c}\text { All } \\
\text { sectors }\end{array}$ & $\begin{array}{l}\text { Public } \\
\text { sector }\end{array}$ & $\begin{array}{l}\text { Private } \\
\text { sector }\end{array}$ & $\begin{array}{l}\text { Private } \\
\text { industry }\end{array}$ & $\begin{array}{c}\text { Private } \\
\text { services }\end{array}$ \\
\hline \multirow[t]{2}{*}{ treat } & 12.58 & -8.928 & 33.59 & 11.91 & 48.50 \\
\hline & (33.68) & $(53.20)$ & $(42.83)$ & $(52.34)$ & (69.71) \\
\hline \multirow[t]{2}{*}{ time } & 0.0155 & 0.0137 & 0.00961 & 0.0313 & -0.00311 \\
\hline & $(0.0207)$ & $(0.0326)$ & $(0.0263)$ & $(0.0318)$ & $(0.0433)$ \\
\hline \multirow[t]{2}{*}{ treat $\times$ time } & -0.00586 & 0.00492 & -0.0164 & -0.00557 & -0.0238 \\
\hline & $(0.0169)$ & $(0.0266)$ & $(0.0214)$ & $(0.0262)$ & $(0.0349)$ \\
\hline \multirow[t]{2}{*}{ Constant } & -32.60 & -27.72 & -22.37 & -62.49 & 1.291 \\
\hline & (38.04) & $(60.01)$ & $(48.40)$ & (58.53) & (79.46) \\
\hline Obs. & 21,860 & 7,352 & 14,508 & 6,988 & 7,179 \\
\hline R-squared & 0.666 & 0.681 & 0.627 & 0.649 & 0.627 \\
\hline
\end{tabular}

Regressions control for all model covariates Robust standard errors in parentheses $* * * \mathrm{p}<0.01, * * \mathrm{p}<0.05, * \mathrm{p}<0.1$ 
Table A6. Treatment effect, 1997-2000, full-time workers on p.c.

(Dependent variable: $\operatorname{lnw}-\operatorname{lncpi}$ )

\begin{tabular}{|c|c|c|c|c|c|}
\hline & $\begin{array}{c}\text { All } \\
\text { sectors }\end{array}$ & $\begin{array}{l}\text { Public } \\
\text { sector }\end{array}$ & $\begin{array}{l}\text { Private } \\
\text { sector }\end{array}$ & $\begin{array}{c}\text { Private } \\
\text { industry }\end{array}$ & $\begin{array}{l}\text { Private } \\
\text { services }\end{array}$ \\
\hline \multirow[t]{2}{*}{ treat } & (0.906*** & $0.935 * * *$ & $0.898 * * *$ & $0.835 * * *$ & $0.956 * * *$ \\
\hline & $(0.00560)$ & $(0.00940)$ & $(0.00686)$ & $(0.00880)$ & $(0.0105)$ \\
\hline after & $(0.00610)$ & $(0.0103)$ & $(0.00735)$ & $(0.0100)$ & $(0.0103)$ \\
\hline \multirow[t]{2}{*}{ treat $\times$ after } & $-0.0311 * * *$ & 0.0127 & $-0.0534 * * *$ & $-0.0546 * * *$ & $-0.0623 * * *$ \\
\hline & $(0.00700)$ & $(0.0115)$ & $(0.00859)$ & $(0.0114)$ & $(0.0126)$ \\
\hline \multirow[t]{2}{*}{ age2 } & $-0.000499 * * *$ & $-0.000243 * * *$ & $-0.000591 * * *$ & $-0.000441 * * *$ & $-0.000726 * * *$ \\
\hline & $(1.53 \mathrm{e}-05)$ & $(2.73 \mathrm{e}-05)$ & $(1.95 \mathrm{e}-05)$ & $(2.45 \mathrm{e}-05)$ & $(3.06 \mathrm{e}-05)$ \\
\hline \multirow[t]{2}{*}{ educ2 } & $0.0740 * * *$ & $0.0725 * * *$ & $0.0701 * * *$ & $0.0786^{* * *}$ & $0.0502 * * *$ \\
\hline & $(0.00394)$ & $(0.00652)$ & $(0.00487)$ & $(0.00582)$ & $(0.00793)$ \\
\hline educ3 & $0.187 * * *$ & $0.220 * * *$ & $0.164 * * *$ & $0.178 * * *$ & $0.149 * * *$ \\
\hline female & $(0.00354)$ & $(0.00532)$ & $(0.00471)$ & $(0.00627)$ & $(0.00684)$ \\
\hline \multirow[t]{2}{*}{ super } & $0.168 * * *$ & $0.160 * * *$ & $0.175 * * *$ & $0.185 * * *$ & $0.186 * * *$ \\
\hline & $(0.00617)$ & (0.00949) & (0.00794) & (0.00996) & $(0.0118)$ \\
\hline \multirow[t]{2}{*}{ inter } & $0.0565 * * *$ & $0.0631 * * *$ & $0.0536 * * *$ & $0.0645^{* * *}$ & $0.0477 * * *$ \\
\hline & $(0.00420)$ & $(0.00640)$ & $(0.00544)$ & $(0.00685)$ & $(0.00830)$ \\
\hline \multirow[t]{2}{*}{ public } & $0.106 * * *$ & & & & \\
\hline & (0.00404) & & & & \\
\hline \multirow[t]{2}{*}{ disability } & $-0.0388 * * *$ & $-0.0286 * * *$ & $-0.0431 * * *$ & $-0.0259 * * *$ & $-0.0616 * * *$ \\
\hline & $(0.00522)$ & $(0.00749)$ & $(0.00682)$ & $(0.00890)$ & $(0.00997)$ \\
\hline \multirow[t]{2}{*}{ indus } & $0.165 * * *$ & $0.129 * * *$ & $0.161 * * *$ & & \\
\hline & $(0.0156)$ & $(0.0342)$ & $(0.0179)$ & & \\
\hline \multirow[t]{2}{*}{ _Iocc3 } & $0.278 * * *$ & $0.259 * * *$ & $0.285 * * *$ & $0.212 * * *$ & $0.339 * * *$ \\
\hline & $(0.00740)$ & $(0.00995)$ & $(0.0101)$ & $(0.0137)$ & $(0.0145)$ \\
\hline \multirow[t]{2}{*}{ _Iocc4 } & $0.186 * * *$ & $0.120 * * *$ & $0.231 * * *$ & $0.165 * * *$ & $0.282 * * *$ \\
\hline & $(0.00651)$ & $(0.00861)$ & $(0.00873)$ & $(0.0119)$ & $(0.0128)$ \\
\hline _Iocc5 & $0.0231 * * *$ & $0.124 * * *$ & $-0.0213 * *$ & $0.0715 * *$ & 0.00531 \\
\hline & $(0.00771)$ & $(0.0111)$ & $(0.0100)$ & $(0.0282)$ & $(0.0127)$ \\
\hline _Iocc6 & 0.000106 & 0.0305 & -0.00990 & $-0.183 * * *$ & -0.0176 \\
\hline & $(0.0189)$ & $(0.0298)$ & $(0.0237)$ & $(0.0484)$ & $(0.0563)$ \\
\hline _Iocc7 & $0.0777 * * *$ & $0.100 * * *$ & $0.0777 * * *$ & $0.0563 * * *$ & $0.0942 * * *$ \\
\hline & $(0.00655)$ & $(0.0121)$ & (0.00799) & $(0.0103)$ & $(0.0147)$ \\
\hline _Iocc8 & $0.0910 * * *$ & $0.138 * * *$ & $0.0851 * * *$ & $0.0587 * * *$ & $0.0935 * * *$ \\
\hline & (0.00709) & $(0.0126)$ & $(0.00865)$ & $(0.0111)$ & $(0.0145)$ \\
\hline Constant & $-3.932 * * *$ & $-3.450 * * *$ & $-4.028 * * *$ & $-3.591 * * *$ & $-4.131 * * *$ \\
\hline & $(0.0282)$ & $(0.0573)$ & $(0.0337)$ & $(0.0389)$ & $(0.0441)$ \\
\hline Observations & 43,291 & 14,239 & 29,052 & 13,644 & 14,900 \\
\hline $\mathrm{R}$-squared & 0.692 & 0.711 & 0.657 & 0.668 & 0.655 \\
\hline
\end{tabular}

Robust standard errors in parentheses

$* * * \mathrm{p}<0.01, * * \mathrm{p}<0.05, * \mathrm{p}<0.1$ 